\title{
How Does Storing Containers on Farmers Stored Boro Rice Seed Affect the Seed Qualities?
}

\author{
Muhaiminur Rashid $^{1}$, Ismail Hossain ${ }^{2}$, Kamrul Hassan ${ }^{3, *}$, Fuad Mondal ${ }^{3}$ \\ ${ }^{1}$ Regional Farm Broadcasting Officer, Agriculture Information Service, Ministry of Agriculture, Bangladesh \\ ${ }^{2}$ Department of Plant Pathology, Bangladesh Agricultural University, Bangladesh \\ ${ }^{3}$ Department of Entomology, Sylhet Agricultural University, Bangladesh
}

Copyright $\bigcirc 2017$ by authors, all rights reserved. Authors agree that this article remains permanently open access under the terms of the Creative Commons Attribution License 4.0 International License

\begin{abstract}
The experiment was conducted at Laboratory of Plant Pathology, Bangladesh Agricultural University (BAU), Mymensingh and Seed Pathology Centre, BAU, Mymensingh during 2010 to 2014 to investigate the effect of storing containers on moisture content, germination percentage, seedling vigor, apparently healthy of seeds and infection of rice stored seeds. The rice seed samples of cv. BR14, BRRI dhan28, BRRI dhan29 and Guti were collected from 36 farmers belonging to the individual villages at Ishwarganj Upazila under Mymensingh District. Four types of storing containers were used by farmers own selves following traditional practices. Storing containers were gunny bag lined with polythene, bamboo bin lined with polythene, gunny bag and earthen pot locally called motka. The highest percentage of moisture content was in gunny bag $(14.32 \%)$ and the lowest in gunny bag lined with polythene $(12.59 \%)$ similarly best germination was in gunny bag lined with polythene (78.04\%) and worst in motka $(65.16 \%)$ consequently maximum vigor index was shown in gunny bag lined with polythene (1756) and minimum in motka (1458). The experiment also found the highest percentage of apparently healthy seeds in gunny bag lined polythene (55.01\%) and lowest in motka $(46.42 \%)$.Sequentially maximum seed borne fungi infection occurred in gunny bag $(28.98 \%)$ and minimum infection in bamboo bin lined with polythene (22.70\%). The result of the experiment evidently proved that polythene sheet was the key indication to protect the quality of seeds. On the other hand, the earthen pot or motka was the worst material to deteriorate the quality of seeds during storing time.
\end{abstract}

Keywords Seed Germination and Infection, Storage Container, Rice Variety

\section{Introduction}

Rice (Oryza sativa) is a staple food and leading food sources for nearly one-half of the world's humankind especially in Bangladesh. Approximately, $77 \%$ of the total cultivated land covering 10.43 million hectares is under rice cultivation in Bangladesh BRRI [8].Currently, the total annual rice production is around 347.09 million tons [4]. Besides, the annual population growth rate is quite high, $1.37 \%$ per annum. The national average yield of rice in Bangladesh is only 4.4 ton per hectare [10]. The average yield of rice in China, Japan and Korea is 6-6.5 T/ha which is much higher than the yield of Bangladesh [7]. Rice production was highest in Mymensingh region in respect of all other regions of Bangladesh. The total rice production in Mymensingh region is around 12.16 lac hectares and production is about 38.95 lac tons [11]. The boro rice production is about 5.98 lac hectares and production is about 22.69 lac tons. Use of poor quality rice seeds brings down the productivity of modern cultivars in its genetic potential [16]. Poor quality of rice seeds caused infection by pathogens viz. fungi, bacteria and nematode [16]. Farmers usually use motka, bamboo bin and dole for storing rice seed in Bangladesh. These containers are not airtight. Consequently seed absorbs moisture that favors the growth and development of storage pests and diseases. Both of insect infestation and fungal infection lead to deterioration of quality and loss of viability of seeds. Storage insects and fungi may cause discoloration and reduce viability of seeds thereby lowering the market value of seeds $[9,17]$. Species of Aspergillus and Penicilium are the dominant storage fungi. Previous studies showed that quality of farmers seed may be deteriorated due to improper storage practices [17,21]. Very few researches have been conducted in regarding effects of storage containers on farmers stored boro rice seed. Therefore, this research aims to investigate the effects of storage containers on farmers stored boro rice seed in the selected location "Ishwarganj Upazilla", Mymensingh, Bangladesh.

\section{Materials and Methods}

The experiment was conducted in Laboratory of Plant 
Pathology Department, Bangladesh Agricultural University, Mymensingh and Seed Pathology Centre, BAU, Mymensingh from 2014 to 2016. Farmers were selected from twelve unions under Ishwarganj Upazila, Mymensingh for studying. For collection of seed samples, farmers were randomly selected from three villages of each union representing each ward of particular union. Finally 36 seed samples were randomly selected from the 36 different villages at Ishwarganj, Mymensingh. Seed samples were drawn following the rules of International Seed Testing Association (ISTA) [15].Thus each sample was taken $0.5 \mathrm{~kg}$ taken in brown paper bag which was placed in a cloth bag and then brought directly to the Seed Pathology Center (SPC) and kept in the refrigerator at $5 \pm 1{ }^{\circ} \mathrm{C}$ until for subsequent studies. Around $40 \mathrm{~g}$ seeds were taken for dry inspection of seeds measuring apparently healthy seeds following standard procedure ISTA [15]. Seeds were divided into eight components viz. apparently healthy seed, discolored seed, spotted seed, insect damaged seed, deformed seed, chaffy seed, varietal mixture and inert matter. Germination test of the collected seed sample was done in sand using tray method. Plastic trays (18' x 9) were used for the purpose. Seeds were sown in sand in each plastic tray in four lines ( 25 seeds/line). For each samples altogether 400 seeds were tested for germination. Germination was recorded twice at 5 and 14 days after sowing. Total germinated seeds, normal seedlings, abnormal seedlings, non-germinated seed and diseased seedlings were counted and expressed in percentages. Seedling vigor index test was done in sand using tray method. For each sample 400 seeds were tested. After 20 days of tested seeds shoot and root length were measured by using measuring scale. Fifteen seedlings from each tray were randomly selected for measurement of shoot or root length. The seedling vigor was determined following the formula of [5] as shown below: Vigor index $=$ (mean of root length + mean of shoot length) $\mathrm{X} \%$ of seed germination. To detect the seed borne pathogens associated with the seeds in seed samples the Blotter method was used by following International Rules for Seed Testing ISTA [15]. In this method, three layers of blotting paper (What man filter No. 1) were soaked in sterilized water and placed at the bottom of 9 $\mathrm{cm}$ diameter plastic Petridis and thereafter 25 seeds were plated. Eight replicates were used for each sample where 200 seeds were needed. The seeds in the Petri dishes were incubated at 20 under alternation cycles of 12 hours near ultraviolet light and darkness for 8 days. After incubation the seeds were examined under sterio-binocular microscope in order to record the incidence of different seed borne fungi. For proper identification of fungi, semi-permanent slides were prepared from the fungal colony and observed under compound microscope. Germination of these incubated seeds was recorded. The results were presented as percent incidence for individual pathogens. Collected data were analyzed following the analysis of variance (ANOVA). Least Significant Difference (LSD) was done to determine the differences among the treatments.

\section{Results and Discussions}

It was found that the efficiency of storage devices was varied in respect of seed quality of boro rice seed. Aeration is great factor for deteriorating of seed quality which prevents using by polythene sheet or metal substance. Studies recorded germination percentage of seeds in organic cocoon (91\%), polythene bag (80\%), polythene in Gunny bag (79.67) and Gunny bag (68\%) respectively [1].

\subsection{Effect of Storing Containers on Moisture Content of Seed Samples}

In respect of containers, the highest percentage of moisture content was in gunny bag $(14.32 \%)$ and the lowest in gunny bag lined with polyphone (12.59\%) shown in Fig 1.

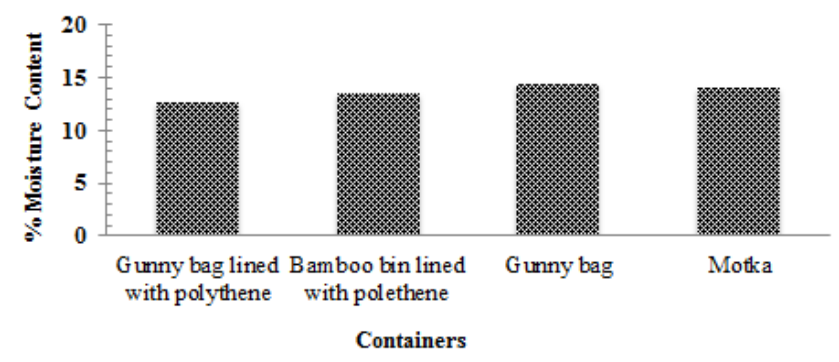

Figure 1. Effect of storing containers on moisture content of seed samples

The upper limits of moisture content of rice13\% [14]. In Bogra the moisture content of farmers saved seeds ranged from 12.30 to $14.40 \%$ [20]. The moisture content of farmers' seeds collected from Rajshahi, Bogra and Rangupur reported ranged from 7.0 to $13.9 \%$ that varying with respect to crop season farmers and location of seed collection, But in 2003 they reported that the moisture content of farmers' rice of the same locations ranged from $12.87 \%$ to $13.30 \%$ [12]. It indicates that moisture content may vary from farmers to farmers as well as location to location. Usually, moisture content can be fluctuated due to storing systems of farmers.

\subsection{Effect of Storing Containers on Germination Percentage and Vigor Index of Seed Samples}

The highest percentage of germination was in gunny bag lined with polythene $(78.04 \%)$ and the lowest in motka $(65.16 \%)$. The highest percentage of vigor index was in gunny bag lined with polythene (1756) and the lowest in motka (1458) shown in Fig. 2.a and Fig. 2.b respectively.

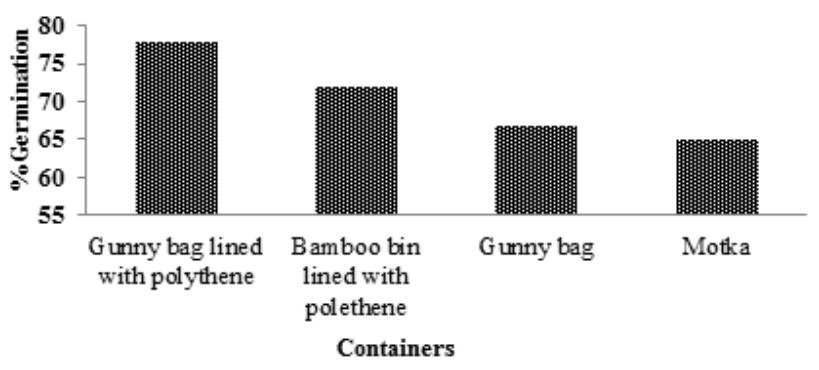

Figure 2a. Effect of storing containers on germination percentage of seed samples 


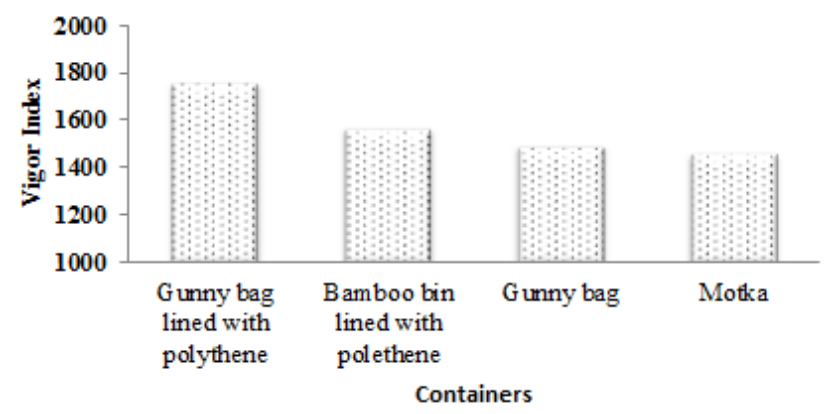

Figure 2b. Effect of storing containers on vigor index of seed samples

Highest germination percentage was found by storing seeds in polyethylene bag than tin container and the lowest in earthen pitcher [18]. Another studies revealed that uses of nine different types of rice seed storage structures, namely dole, motka, kolshi, steel drum, kerosene tin, polythene, motka, gunny bag and plastic drum had a clear impact on seed quality. The outcome of the results indicated that the highest insect population seed damage and weight loss were recorded in gunny bag and lowest were in metal structures (steel drum of kerosene tin) followed by polythene or motka. Seeds stored in organic cocoon performed much better compare to rexin cocoon, polythene bag, poly with gunny bag and gunny bag in maintaining higher germination due to low moisture content which may reduce respiration as well as the incidence of insect and pathogens also low caused of low oxygen supply [1]. Polythene type's bags and rexin cocoon were the best device to maintain a fair germination range of 82 to $87 \%$ [2]. It was reported that highest normal seedlings $81 \%$ was obtained by storing seeds in tin container and lowest in $66 \%$ by using seeds of gunny bags and viability of seeds decreased with the increase of storage period. They also found the association different fungi with seeds sample and their prevalence was higher when stored in gunny bags [19].

\subsection{Effect of Storing Containers on Apparantly Healty Seeds and Infected Seeds of Seed Samples}

The highest percentage of healthy seed was in gunny bag lined with polythene $(55.01 \%)$ and the lowest in motka $(46.02 \%)$ and the highest diseased infected seed in gunny bag (38.98\%) shown in Fig. 3.a and the lowest in Bamboo bin lined with polyether $(22.70 \%)$ shown in Fig. 3.b.

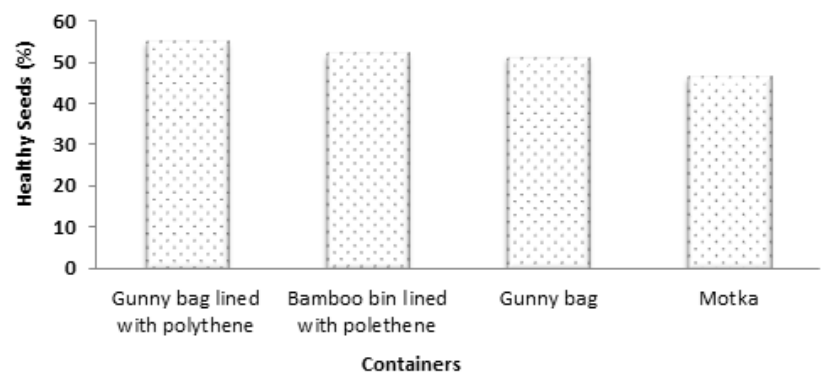

Figure 3a. Effect of storing containers on apparantly healty seeds of seed samples

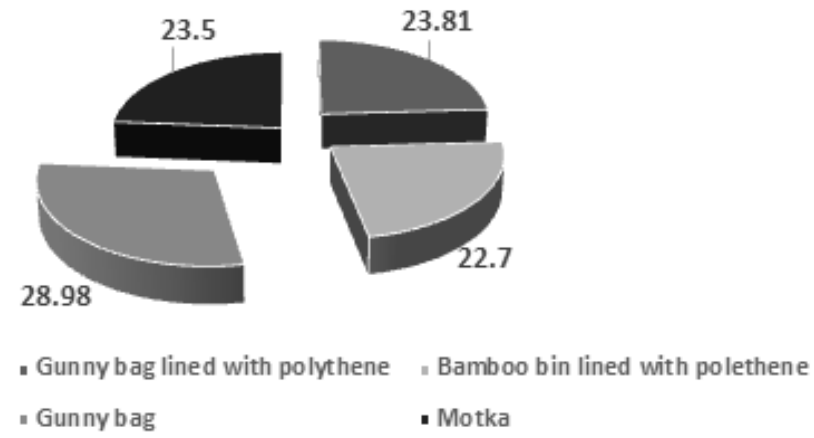

Figure 3b. Effect of storing containers on percent of infected seed of seed samples

Plastic drum with neem leaves rather than motka, painted motka and tin jar was the best for retaining seed quality, having lowest moisture content and minimum insect damage [3]. Another study shown that the moisture content and black point infection increased, the seed germination decreased with the increase of storage period [13]. Reported that number of insect damage seeds, insect population and fungi infection varied with respect to storage containers, storage period and additives used [3,12]. It was showed that gunny bag is the worst compare to metal structures as storage containers for ensuring quality of seeds [13] and also reported that highest germination and lowest prevalence of fungi were recorded in the seeds stored in tin followed by polythene bag and gunny bag with polythene lining [20]. From seed health test by blotter method revealed that six seed borne fungi belonging to five genera viz. Bipolaris oryzae, Fusarium moniliforme, Fusarium oxysporum, Aspergillus flavus, Penicillium spp. And Alternaria padwickii were found to be associated with the seeds. The stored seeds also associated different insects like as rice meal moth and rice beetle. The highest percentage of insects was found in motka consequently the highest infection of seeds from gunny bags. Besides the lowest infestation in the containers where used polythene. They found a positive correlation between increase in population of storage fungi and loss in germination. The findings of the present study have clearly pointed out by different the moisture content, purity, germination, vigor index, and seed infection were strongly affected using by different the containers used by farmers.

\section{REFERENCES}

[1] Alam, M.; M. Ahmed; Mirza Hasanuzzaman and M.O Islam. 2009. Performance of Alternate Storage Devices on Seed Quality of Boro Rice, Middle- East journal of Scientific Research 4(2): 78-83, 2009.

[2] Alam, M.; M. Ahmed; Mirza Hasanuzzaman and M.O. Islam. 2009. Seed Quality of Aman Rice as Affected by some Alternate Storage Devices, American Eurasian journal of Agronomy 2(3): 130-137, 2009. 
[3] Ali, M.A.; M. Akter; M.A Tahar Mia and A.H.M.M Haque.2008 Effect of storage containers and additives on the health and quality of rice seeds. Bangladesh J. Seed Sci. and Tech, 12 (1): 129-132 (2008).

[4] Krishi Dairy. 2017. AIS (Agriculture Information Service). Extension Section-2, Ministry of Agriculture, Bangladesh Secretariat, Dhaka.

[5] Baki, A. and Anderson, J.D. (1973). Vigor Determination in Soybean Seed by Multiple Criteria. Crop Science, 13, 630-633.

[6] Bala, B.k., M.A. Zaman, B.k. Biswas, and A.R. Khondokar.1994. Experimental studies on storage of paddy in different traditional structures, Trope, Sci., 34 (3): 289-296.BBS.2009.

[7] BRRI (Bangladesh Rice Research Institute).2017. Adhunik Dhaner Chas (In Bengali) Joydevpur, Gazipur, $20^{\text {th }}$ edition. June p-5.

[8] BRRI (Bangladesh Rice Research Institute). 2014. Gazipur 1701.

[9] Christensen, C. M and H. H. Kaufmann.1965. Deterioration off stored grains by fungi. Ann. Rev. Phytopath 3:69-89.

[10] DAE (Department of Agricultural Extension). 2016. Field Service Wing. Ministry of Agriculture, Khamarbari, Dhaka-1215.

[11] DAE (Department of Agricultural Extension). 2016. Office of the Additional Director, Mymensingh Region, Mymensingh-2200.

[12] Fakir, G.A.; I. Hossain; M.U. Ahmad; M.K. Anam; M.N. Islam and M. Rahman. 2003. Effect of ash, chalk powder and neem leaf on quality of Boro rice seed stored in gunny bag, motka, plastic drum and tin jar. Review and planning Meeting of the Seed Health Improvement. BRRI, Gazipur, Bangladesh.21-22.

[13] Howlader, M. T. H. 2003. Prevalence of insect pests in rice seed and its loss assessment as influenced by storage structures at Mymensingh Sadar Upazila, Mymensingh. Dept. of Entomology. BAU. Mymensingh.

[14] Henderson and Christensen 1961, Post-Harvest Control of insect and fungi in Seeds. The Yearbook of Agriculture. The United State Department of Agriculture, Washington D C, USA, P 348-353.

[15] International Seed Testing Association (ISTA). 1999. The Rules of Seed Testing.

[16] Mew, T. W. and P. Gonzales. 2002. A Handbook of Rice Seed borne Fungi. International Rice Research Institute, P.O.Box. 933, Manila, Philippines.

[17] Miah, I. H. and G. A. Fakir. 1989. Fungi, moisture content and germination ability of rough rice seeds during storage. Seed Res. 17: 169-173.

[18] Malaker, P. K.; I. H. Mian. 2008. Effect of black point on seed quality and yield of wheat. Bangladesh J. of Plant Pathol. 2002; 18(1/2):65-70.

[19] Naznin, H. A.; M. S. Monjil; M. A. Kashem; M.R. Islam and I. Hossain. 2005. Quality of wheat seeds stored in different containers. Bangladesh J. Seed Sci. and Tech. 9(1\&2)15-18.

[20] Rahman, M.M.K. and G.M.M. Rahman. 1997. Effect of containers and length of storage on germination and seed borne fungi associated with jute seed. Bangladesh J. Plant Pathol. 13(1-2): 13-16.

[21] Rahman, M. and M.A.T. Mia. 1998. Studies on the health status of farmers stored seed of rice. Bangladesh J. Plant Pathol. 14(1\&2):37-40. 